\title{
Electronic Certificate Perspective in Civil Law Evidence
}

\author{
Sepriyadi Adhan S. \\ Faculty of Law \\ Lampung University \\ Lampung, Indonesia \\ sepriyadiadhans@gmail.com
}

\author{
Ati Yuniati \\ Faculty of Law \\ Lampung University \\ Lampung, Indonesia \\ atiyuniati78@gmail.com
}

\author{
Muhammad Labib Muhadz \\ Faculty of Law \\ Lampung University \\ Lampung, Indonesia \\ labibmuhadz@gmail.com
}

\begin{abstract}
The digital era requires humans to be able to work more effectively. Advances in the field of information and electronic transactions that are growing rapidly have brought many changes. With the ease of obtaining and managing information through the use of electronic evidence in the era of globalization, aspects of current civil relations traffic, such as buying and selling online, are not uncommon through cyberspace. Situations like this, if not accommodated in the form of laws and regulations, can create legal uncertainty regarding the practice of transactions conducted electronically (e-commerce). The position of electronic evidence in the process of proving civil cases in court from the juridical-normative aspect has been recognized as evidence legally and firmly in the practice of procedural law applicable in court. The presence of Law Number 11 of 2008 as a form of affirmation (legitimacy), the recognition of electronic information and/or electronic documents and/or their printouts is legally valid evidence and is an extension of legal evidence following applicable procedural law. in Indonesia, as long as the electronic information and/or electronic documents contained therein can be accessed, displayed, guaranteed for its integrity, and can be accounted for so that it can explain a situation. The strength of evidence inherent in an electronic evidence instrument is juridically-normatively equivalent to a document written on paper. This affirmation means that the strength of evidence attached to electronic evidence in civil cases can be equated with the strength of proof of written evidence (letters). The power of electronic evidence does not apply to letters which according to the law must be made in written form; and letters and documents which according to the law must be made in the form of a notarial deed or a deed made by the official making the deed. The power of electronic evidence does not apply to letters which according to the law must be made in written form; and letters and documents which according to the law must be made in the form of a notarial deed or a deed made by the official making the deed. The power of electronic evidence does not apply to letters which according to the law must be made in written form; and letters and documents which according to the law must be made in
\end{abstract}

the form of a notarial deed or a deed made by the official making the deed.

Keywords- Electronic transactions, e-commerce, verification

\section{INTRODUCTION}

The presence of legal values that come from habits in the community regulates the pattern of human life, to create order and legal certainty. Conditions like this can be seen in the order of primitive society though, there has been a set of rules that were formed to regulate the pattern of behavior of the community, even though its nature is still very simple. This is certainly different in the order of modern society, the law, as a rule, has appeared as a code of conduct and as social engineering [1]. The emergence of law in society is an absolute necessity because in regulating behavior between humans and other humans, it is important to make rules that are binding on society. This situation cannot be separated that a social order, which consists of a collection of individuals, ethnicity, and class, cannot be separated from various individual interests that will intersect with the interests of other individuals [2]. The role of an institution (law) in society, absolutely must accommodate the various interests that occur.

Disputes that occur in the community require a set of rules/rules to resolve the dispute. The dispute resolution process taken to reduce conflict and resolve disputes can be broadly divided into two categories, namely litigation and non-litigation processes. Settlement of disputes/disputes through the nonlitigation stage is the stage of dispute resolution outside the court. At this stage, dispute resolution is more directed to peace between the parties. The background for the emergence of non-litigation dispute resolution is when the state through its institutions (courts) is considered unable to resolve disputes. The birth of a court decision stating that the party lost and won, then followed up with the implementation of the court's decision (execution). has sparked a new conflict. The 
implementation of court decisions (executions) is often colored by chaos and even bloodshed by parties who are not satisfied with the decision.

Litigation dispute resolution regulates certain procedures and tools to resolve disputes. The most crucial dispute resolution process in the litigation dispute resolution stage is the problem of proof [3]. Therefore, the essence of proof is very important, because this will lead to whether it is true or not. There are many narrations, stories, or legal histories that show us how because of a mistake in judging the evidence, the innocent party must be imprisoned because the witness lied. Vice versa, the party who has committed a crime is acquitted by the court because of a misjudgment, in terms of insufficient evidence.

Regarding the view of changes to the law, legal experts agree that the law must be dynamic, cannot be static, and must continue to protect the community. There are two very dominant views related to legal changes in people's lives, namely the traditional and modern views. The traditional view holds that society needs to change first, then the law comes to regulate it. According to this view, the law is only a justification for changes that occur in society. Technological advances are used by countries to make it easier for the community, this does not escape the Indonesian government. In addition to the presence of E-KTP as a form of technological progress, another form of technology among the government is electronic certificates [4].

Electronic Certificates hereinafter referred to as eCertificates, are Certificates issued through the Electronic System in the form of Electronic Documents. The implementation of electronic land registration as referred to in paragraph (1) includes land registration for the first time and maintenance of land registration data. The implementation of electronic land registration is implemented in stages determined by the Minister. Support paperless office culture in the digital era, easy to maintain and manage, can be accessed anytime and anywhere, avoids the risk of loss, fire, rain, and theft on physical documents, supports the government's go green program, by reducing the use of paper and ink, simplifying and speeding up the signing process and service, application of digital signatures that ensure data authentication, integrity, and antirepudiation of land certificates [5]. Based on what has been described above, basic research will be carried out with the title: "Electronic Certificate Perspective in Civil Law Evidence".

\section{LITERATURE REVIEW}

\section{A. Evidence in Civil Perspective}

The development of the use of electronic media using the internet has influenced aspects of human needs and behavior. The presence of the internet that knows no boundaries and is borderless has destroyed geographical boundaries, both on a national and international scale. Aspects of human interaction globally allow for various transactions that occur every day [6]. The emergence of electronic commerce transactions (e-commerce) gave birth to electronic transcripts as evidence of grip to the parties in the event of a dispute in the future.

The process of proof in civil cases that only recognizes limited and limited evidence as in Article $164 \mathrm{HIR} / 284 \mathrm{RBg}$ and Article 1866 of the Civil Code brings its problems in the evidentiary process in court. The affirmation of the types of evidence recognized in civil procedural law implies that apart from the evidence explicitly stated in the practice of procedural law, it cannot be recognized/illegitimate as evidence. This, on the one hand, will certainly bring serious problems because it is not uncommon for the practice of civil relations traffic to be carried out through electronic media (internet) such as buying and selling and contractual relationships.

Problems regarding the existence of evidence other than those mentioned in a limited manner in the practice of civil procedural law, as well as the emergence of new evidence (electronic) due to the growing pattern of human civil relations will lead to an atmosphere filled with legal uncertainty. The legal uncertainty that the author means here is the regulatory aspect of electronic evidence that has not been fully accepted in the process of proving civil cases. In the practice of cases in court, the aspect of legal certainty is an important element in the law enforcement process, so that with legal certainty a person's rights will be protected and, aimed at preventing vigilante action (eigenrichting) [7].

Recognition of the position of electronic evidence other than those regulated in a limited and limited manner in terms of legal certainty will be achieved if there is a written legal rule that has been recognized to regulate this matter. The presence of a rule as an institution will have consequences for the implementation of the rules that have become the institution so that anyone who violates it will be punished for the act. Problems that arise in the evidentiary process in civil cases as regulated in HIR and $\mathrm{RBg}$ as Dutch colonial heritage has not accommodated the use and position of electronic evidence in the process of examining civil cases in court. This is a reasonable thing because the position of HIR and $\mathrm{RBg}$ who were born and,

The civil relations that prevailed when HIR and $\mathrm{RBg}$ were applied in the practice of civil procedural law during the Dutch colonial era were only limited to conventional civil relations [8]. The implementation of HIR and RBg after the independence of the Republic of Indonesia as a guideline for examining cases in court which includes criminal and civil cases is recognized by the government based on Law Number 1 of 1951. principles adopted by HIR and $\mathrm{RBg}$. The issue of the codification of the new civil procedural law. 


\section{B. Position of Electronic Evidence}

The current position of electronic evidence in civil cases is seen as no longer having to rely on the type of evidence that has been limitedly determined by the laws and regulations [9]. The pattern and behavior of human life that is increasingly developing, has also influenced aspects of the traffic in civil relations which have continued to this day. The presence of Law Number 11 of 2008 concerning Information and Electronic Transactions (ITE) as a form of affirmation of the recognition of electronic transactions in civil relations traffic, and the use of electronic transcripts as a form of evidence in court has had a considerable influence on the development of ongoing civil relations now.

Recognition of the position of electronic evidence in the process of proving civil cases is not only limited to aspects of legal recognition. The process of proof in criminal and civil cases is one of the important elements so that the recognition of the position/existence of the electronic evidence, can guarantee legal protection and certainty between the parties [10]. The formulation of article 5 paragraph (1) in Law Number 11 of 2008 concerning Electronic Information and Transactions (ITE) states that Electronic Information and/or Electronic Documents are legal evidence Furthermore.

The definition of Electronic Information in the general provisions of Article 1 of Law Number 11 of 2008 is stated as one or a set of electronic data, including but not limited to writing, sound, images, maps, designs, photographs, electronic data interchange (EDI), electronic mail ( electronic mail), telegram, telex, telecopy or the like, processed letters, signs, numbers, access codes, symbols, or perforations that have meaning or can be understood by people who can understand them. The formulation of the meaning of electronic information as stated in the general provisions of Article 1 paragraph (1) of Law Number 11 of 2008 is broader than the information that is poured/written in writing on paper.

This is possible to do given the nature of electronic information that is easy to transfer into several media/forms [11]. Differences Electronic information compared to information that is conventionally written on paper, which contains signs, access codes, symbols, or perforations. This is certainly different from information obtained through conventional means, such as information contained on paper. For example, the author will present an example of the difference in evidence that has been mentioned in limited terms in Article 164 HIR/284 RBg/1866 of the Civil Code, namely written evidence or letters. It is further stated in Article 1 paragraph (4) of Law Number 11 of 2008, electronic documents are any electronic information, which is created, sent, received, or stored in analog, digital, electromagnetic, optical, or similar forms that can be viewed, displayed, and/or heard through a computer or electronic system, including but not limited to writing, pictures, maps, designs, photographs or the like, letters, signs, numbers, access codes, symbols or perforations that have meanings or meanings that can be understood by people who can understand.

\section{Information Security Standards}

The existence of these regulations can serve as a legal umbrella for securing national information systems and demonstrate the government's level of awareness in terms of information security. Although the laws and regulations in the field of information security are still weak. Information security activities cannot be carried out effectively without the mobilization of a unified administrative, physical and technical plan.

Every element of the realization of information security needs to be related to established security standards. Information security standards must be specific and specific so that they can be applied to all areas of information security. All countries need to develop standards after analyzing administrative, physical, and technical security standards that are widespread around the world. The standard should be compatible with the general ICT environment. Information security standards include integrated information security activities such as information security policy formulation, information security organization preparation and operation, human resource management, physical security management, technical security management, security audit management, and business continuity. It is intended to be recommended. Many organizations recommend information security standards.

The main purpose of implementing Information Security Standards is to make government information security activities efficient and effective so that it is not easy for foreign parties to dismantle them. In addition, Information Security Standards will make it easier to create regulations that can provide decisions whether an information security activity is good or not, whether any information needs to receive security treatment or not and can also determine to what level of security is needed, and so on [12]. So that regulations on information security do not need to create any more specialized agencies/institutions to make decisions on information security or the level of confidentiality of data/information.

Information security standards emphasize the aspects of requirements, procedures, policies, management, and education and training. The standardization referred to here is not a technical standard (specification), the direction of a technology or product, and a collection of tips and is not a guarantee of the functioning of an information security tool. This approach allows information security standards to be applied in various types of organizations.

Based on the process, there are three stages in the standardization process (International Organization for 
Standardization/International

Electrotechnical

Commission, 1996), which are as follows [13]:

- Specification: develop nomenclature and identify issues to be raised.

- Identification of choices: identify the solution to the problem and choose the "optimal" solution.

- Acceptance: establishing a solution, making it known to the industry so that a uniform solution is accepted.

\section{RESEARCH METHODS}

Research has another term or known as research. The research comes from English, namely research which comes from the word re (re) search (search) this research which has the term research can be interpreted as searching again. This research activity is based on the curiosity of someone who is then referred to as a researcher in carrying out research activities. Research is a form of expression of curiosity carried out in the form of scientific research activities. This research is carried out with a sense of trust in the object being researched by finding out the causes and effects that arise or occur in the object of research.

This study uses a normative research method. According to Peter Mahmud Marzuki [14], normative legal research is a process to find a rule of law, legal principles, and legal doctrines to answer the legal issues faced. In this type of legal research, the law is often conceptualized as what is written in legislation or the law is conceptualized as a rule or norm which is a benchmark for human behavior that is considered appropriate.

Based on the problem approach and the required data sources, the data collection in this study was carried out using a literature study by reading, quoting, taking notes, and identifying data that was following the problem, and collaborating with the data of applicable laws and regulations. After collecting data, then processing the data obtained is used to analyze the problems studied. Data processing in this study was carried out by Data examination, classification, and data compilation.

\section{RESULTS}

The development of aspects of social life affects the economy, society, and culture, this happens because of the influence of information technology. The changes that appear are changes in the economic field. Significant developments change the conventional economic system or manually into a digital economic system with electronic tools. In the current era of globalization, the most prominent characteristic of the economy is that it is fast-paced which encourages people to enter the era of free markets and free competition. Internet technology has a huge influence on world influence. The internet has brought the world economy into a new phase which is more popularly known as digital economics so that its existence is marked by the increasing number of economic activities that use the internet as a medium of communication, collaboration, and cooperation [15]. The use of electronic systems in the business world is widely used today because it offers convenience, speed, and efficiency. However, e-commerce activities are no longer simple, because their activities are no longer limited by the territory of a country, which is easily accessible anytime and from anywhere. Losses can occur, both to the perpetrator of the transaction and to other people who have never made a transaction. The losses suffered by the parties will certainly lead to conflicts that will reach the court process. The purpose of the parties who feel the loss of litigation in court is of course to complete the case completely with court decisions that already have permanent legal force (inkrah).

According to the Indonesian civil procedural law system, according to the Herziene Indonesiche Reglement/Rechtsreglement voor de Buitengewesten (H.I.R/R.Bg) system, judges may only make decisions based on valid evidence. That is, what is regulated in H.I.R/R.Bg which can be used by judges. However, the development of the times has led to an electronic nature, including the emergence of electronic evidence. One of the electronic pieces of evidence is electronic documents. The electronic document is one of the electronic evidence which is regulated expressly in Law no. 11 of 2008 concerning Information and Electronic Transactions. Where in this law, it is expressly stated that it is legal as evidence in court, especially in civil courts. In this section, what becomes very interesting is the issue of the existence or existence of electronic documents in other laws and regulations. Because after knowing the types of electronic documents in the previous description, an inventory of the existence of electronic documents in other laws and regulations can be carried out.

Regarding evidence that applies in Indonesian civil procedural law, electronic documents appear as new evidence that has an expansionary nature. This can be seen in Article 5 paragraph 2 of Law no. 11 of 2008 concerning Information and Electronic Transactions reads: "Electronic Information and/or Electronic Documents and/or their printed results as referred to in paragraph (1) is an extension of valid evidence following the procedural law in force in Indonesia". The meaning of the word expansion if understood from the meaning of the vocabulary is to expand or expand. However, the meaning of the word should be seen as one part of legal reform because the emergence of electronic documents has perfected the existing laws and regulations so that they do not lag behind the times [16]. The existence of electronic documents will be increasingly recognized if the Civil Procedure Law Bill with the sound of article 90 paragraph (1) does not change and is ratified by the House of Representatives (DPR). Electronic documents, which are a form of civil 
procedural law reform in several court decisions, have been shaken by their existence.

Proving is convincing the judge of the truth of the arguments or arguments put forward in a dispute so that it appears that proof is only needed in a dispute or case before a judge or court. Meanwhile, evidence in civil cases as regulated in Article 1866 of the Civil Code includes 1. Written evidence 2. Witnesses 3. Allegations 4. Confessions 5. Oaths. 2 Along with the development of the era which increasingly uses the sophistication of digital technology, then sometimes the evidence is no longer appropriate ten years ago. The problem is so visible in written evidence or letters, where the evidence is only divided into 2 (two) forms, namely, deed and not deed. Both must be in a conventional form, whereas with the development of increasingly sophisticated technology now there is a letter or deed that is no longer in the form of a conventional or electronic deed. Indonesia is entering the era of globalization which encourages the development of technology and business activities of businesspeople in a more effective and efficient direction, namely e-commerce [17].

Human life, which is increasingly developing in various sectors of life, has influenced and changed various patterns of human thought today. The rapid development and pace of life as a result of the advancement of Science and Technology (IPTEK), has brought significant changes, both in the way of thinking, acting, and behaving among others. The system of human interaction in the era of globalization, which takes place as if it were borderless, brings considerable influence and benefits. Practices in the traffic of buying and selling relationships and buying transactions nowadays are not uncommon to use electronic media in conducting this buying and selling relationships.

Civil relations that initially took place conventionally, in the form of buying and selling, leasing, and other agreements that took place conventionally, slowly turned into the practice of buying and selling, leasing, and agreements made electronically. The presence of electronic media in addition to providing benefits on the one hand also contains a fairly large potential danger. The emergence of new types of crime, for which there is no regulation, makes law enforcement officers seem unable to act because the legal regulations do not exist/sufficiently. The emergence of events as mentioned above gives the impression that the progress achieved by humans today, in the era of globalization as a result of the development of Science and Technology (IPTEK) is like a doubleedged sword.

E-commerce activities or electronic transactions in Indonesia have been regulated in Law Number 11 of 2008 concerning Electronic Information and Transactions, then updated in Law Number 19 of 2016 concerning Electronic Information and Transactions.
With online transactions, of course, the position of producers and consumers must be protected to provide security to create trust between the two parties. This trust is obtained by giving legal acknowledgment to electronic writing or electronic documents and assuming their legal position in the eyes of the law. The existence of a Digital Signature has been regulated in Article 1 number 12 of Law Number 19 of 2016 concerning Electronic Information and Transactions "Electronic Signature is a signature consisting of Electronic Information that is attached, associated or related to other Electronic Information used as a means of verification and authentication".

The existence of electronic evidence has also been recognized in Article 5 paragraph (1) "Electronic Information and/or Electronic Documents and/or their printed results are legal evidence", and Article 5 paragraph (2) "Electronic Information and/or Documents The electronic and/or printout as referred to in paragraph (1) is an extension of valid evidence following the applicable procedural law in Indonesia." Article 5 paragraph (3) of the Electronic Information and Transaction Law is expressly regulated that "Electronic Information and/or Electronic Documents are declared valid if they use the Electronic System following the provisions outlined in this Law."

The success of an electronic business transaction can be judged from three criteria, namely; in terms of access (access), benefits (benefits), and community (community). An electronic transaction can be categorized as good if it can be accessed quickly, safely, the application is easy to use and the coverage is wide. In addition, electronic transactions can provide benefits such as increasing efficiency, flexibility, expanding the market (expand market), and responding to customers in real-time. From the community side, electronic transactions are categorized as good if they can make people connected, change culture and mindset (mindset), successfully change the market ecosystem environment [18].

The three keys to the success of an electronic business transaction are carried out in a business mechanism (enterprise) and based on applicable rules and policies. Electronic transactions run in an information and communication technology infrastructure/means, namely the internet. Even though it is supported by the sophistication of modern means of communication, the internet is very vulnerable to information security attacks. Without an information security system, electronic transactions become very vulnerable to information security disturbances that can cause discomfort for the perpetrators of electronic transactions. Inconvenience in electronic transactions has led to the development of issues regarding trust in electronic transactions both nationally, regionally, and globally. There are four criteria for information security in electronic transactions, namely: confidentiality, authenticity, integrity, and non-repudiation [19]. 
The provisions of Article 5 paragraphs (1) and (2) of the ITE Law have regulated the position of Electronic Information and/or Electronic Documents as legal evidence and the expansion of legal evidence following the applicable procedural law in Indonesia. Electronic information phrases and/or electronic documents as evidence are carried out in the context of law enforcement at the request of the police, prosecutors, and/or other law enforcement institutions stipulated under the law as stipulated in Article 31 paragraph (1) UU ITE (MK Decision Number 20/PUUXIV/2016). Following the content of the application in the Constitutional Court, the decision is directed to a criminal legal process and not a civil law process.

The legal requirement for electronic documents is to use an electronic system that complies with UU ITE's provisions, especially Article 6 of UU ITE. That is, "electronic information and/or electronic documents can access, display, warrant, and offset the integrity of the information contained therein, thus explaining the situation.

The Supreme Court's acknowledgment of electronic documents in the judicial system was first known through the Supreme Court Circular Letter (SEMA) Number 14 of 2010 concerning Electronic Documents as Completion of Applications for Cassation and Review. This SEMA aims to improve the efficiency and effectiveness of the case file mutation process as well as support the implementation of transparency and accountability as well as public services at the Supreme Court and the Judicial Body under it. However, this SEMA does not regulate electronic documents as evidence, but electronic documents in the form of decisions and indictments that are included on compact discs, flash disks / sent via email as a complete application for cassation and review.

This SEMA has been amended based on SEMA 1 of 2014 concerning Amendments to SEMA 14 of 2010 concerning Electronic Documents as a complement to the Application for Cassation and Review. This SEMA change was made concerning the file checking system from a rotating system to an electronically directed shared reading system. In the SEMA points, there are additional details of the documents that must be submitted by the litigants electronically but once again the importance is not concerning electronic evidence. Another difference with the old SEMA is the way documents are included through the data communication feature (legal remedies menu) in the Supreme Court decision directory because the old method through compact disks and sending edocuments has several obstacles including unreadable data, missing data storage devices, and others other.

If the electronic document has been submitted in court according to the procedure accepted by all litigants, the next question is what if the opposing party wants to see the electronic document that will be submitted as evidence? The provisions of Article 137 of
HIR stipulate that "Parties may demand to see their opponent's certificates and vice versa, which letters are submitted to the judge for that purpose". In maintaining the principle of transparency of evidence in court, the provisions of $137 \mathrm{HIR}$ must also apply to electronic documents when the opposing party asks to be shown. For this reason, technological devices in the form of laptops or projectors are needed to be able to display/show electronic documents and even this is not regulated.

In addition, electronic documents containing electronic signatures must meet several criteria in Article 11 of the UU ITE so that they have legal force and legal consequences, namely a. related electronic signature creation data only to the signer, $b$. the electronic signature creation data at the time of the electronic signing process is only in the power of the signer, c. all changes to the electronic signature that occur after the signing time can be known, d. all changes to the electronic information related to the electronic signature after the signing time can be known, e. there are certain methods used to identify who the signatories are, and f. there are certain ways to show that the signer has given consent to the associated electronic information. The criteria points above also contain aspects of electronic document security as mandated in Article 12 paragraph 1 of the UU ITE, including authenticity (authentication), integrity (integrity), and non-repudiation. The following is the division of criteria in Article 11 of the ITE Law and aspects of security guarantees in Article 12 of the ITE Law:

- related electronic signature creation data only to the Signer (Authenticity/Authentication);

- the electronic signature creation data at the time of the electronic signing process is only in the power of the signer (Authenticity/Authentication);

- all changes to the electronic signature that occur after the time of signing can be known (Integrity);

- any changes to the electronic information related to the electronic signature after the time of signing can be known (Integrity);

- there are certain methods used to identify who the signatories are (Non-Repudiation);

- there is a certain way to show that the signer has given consent to the related electronic information (Anti-Repudiation/NonRepudiation)

Other acknowledgments of electronic documents are increasingly stated in the Supreme Court Regulation (PERMA) Number 3 of 2018 concerning the Administration of Cases in Courts Electronically. In the provisions of Article 17 PERMA it is regulated that 
"The Court issues a copy of the decision/stipulation electronically. A copy of the Court's decision/decision which is published electronically is sent to the parties no later than 14 (fourteen) days from the decision/stipulation except for bankruptcy/PKPU", sending done through electronic domicile. However, following the provisions of Article 23 paragraph (3) of the Decision of the Director-General of the General Judiciary Agency Number 271/DJU/SK/PS01/4/2018, it is regulated that "a copy of the decision/stipulation cannot be used as legal evidence". This means that the General Courts in particular are still obliged to issue decisions/decisions in printed form that can be used as evidence.

A copy of the decision in the form of an electronic document can later be signed electronically if it has been certified and the copy of the decision document does not need to be matched with the original as written evidence according to Article 1.888 of the Civil Code. Following the purpose of the Elucidation of Article 6 UUITE, "The authenticity of the decision in the form of an electronic document with the original decision signed by the Panel of Judges does not need to be compared because, within the scope of the electronic system, the original information and its copy are no longer relevant to be distinguished because the Electronic System operates differently. duplication which results in the original information being indistinguishable from the copy" [20].

To carry out trusted electronic transactions (trusted e-transactions), the regulation stipulates that business actors who offer products through the Electronic System must provide complete and correct information related to contract terms, manufacturers, and products offered (Article 9 of the ITE Law). In addition, the regulation also stipulates that business actors who operate electronic systems can be certified by the Reliability Certification Agency (Article 10 of the ITE Law). Article 41 of PP PSTE also explains that the implementation of Electronic Transactions in the public or private sphere using Electronic Systems for the benefit of public services must use Reliability Certificates and/or Electronic Certificates.

Electronic transactions must be secure and reliable. Therefore, every electronic transaction that uses an electronic system is required to have a reliability certificate and an electronic certificate. Such is the mandate of Articles 41 and 42 of Government Regulation (PP) No. 82 of 2012 concerning Electronic System and Transaction Implementation (PP PSTE). Information security standards emphasize the aspects of requirements, procedures, policies, management, and education and training. The standardization referred to here is not a technical standard (specification), the direction of a technology or product, and a collection of tips and is not a guarantee of the functioning of an information security tool. This approach allows information security standards to be applied in various types of organizations.

Aspects of civil relations at this time have used a lot of electronic media (internet) in conducting various transactions. Trade transactions carried out through electronic media or commonly called Electronic commerce (E-commerce) leave various problems that have not been regulated. Circumstances that occur where there is no regulation regarding this matter will bring logical consequences to the absence of the rule of law, or more accurately said to be an atmosphere of legal vacuum. The problem that occurs in the current civil relationship traffic is the practice of electronic transactions that give birth to certain electronic transcripts as evidence of the existence of the transaction so that it can be used as a guide for the parties in the event of a dispute in the future [21].

Disputes on civil relations in the Court are aimed at seeking and finding formal truths. Formal truth contains the notion of truth based on law. The absence of laws and regulations governing the problems of transactions conducted electronically (E-commerce), will bring the parties in a situation where there is no legal certainty in it. The basic provisions in the practice of civil procedure, hint at the principle of ius curia novit which means judges are considered to know the law. This means that the judge may not refuse to try a case because the legal rules do not exist/complete enough.

However, in the absence of regulations governing certain matters, law enforcers in this case the judges are required to make a legal breakthrough. customers in transactions. The convenience obtained is, the customer (customer) is not required to meet directly with the seller (merchant). In addition, the goods offered in electronic commerce transactions (E-commerce) are also diverse/very varied. This phenomenon, although the government has been slow to anticipate with the presence of Law Number 11 of 2008 concerning Electronic Information and Transactions (ITE), is considered sufficient to provide an answer to the response to the use of technology in electronic transactions.

One of the problems that arise in the use of electronic transactions, is the existence of electronic evidence, which does not only dwell on the legal aspect but goes further into the area of evidentiary value and evidentiary standards. The use of electronic transactions in civil relations traffic requires clear regulations regarding the general provisions of electronic transactions in practice and their use in the field of civil law. The presence of a rule must contain details regarding issues that arise in the future, to answer a series of things that can become obstacles in civil disputes. This is very important to do to answer efforts towards the development of legal certainty and renewal of procedural law in civil cases. 
The nature of electronic transactions that can be transferred or transformed into several forms such as Compact Disc Read-Only Memory (CD_ROM) and Write On reading Many (WORM) which can maintain the authenticity and guarantee the level of security against the authenticity of a document. The presence of Law Number 8 of 1997 concerning Corporate Documents has reached the acknowledgment of the existence of documents that are transferred or transformed into electronic media. Article 12 of the law states explicitly the transfer of company documents that are transferred in the form of microfilm and other media.

The series of stages of proving civil cases in court, referring to and based on the provisions of evidence in civil procedural law. The provisions outlined in the civil procedural law must be obeyed by all parties, even including judges who handle cases in court. In principle, the provisions of evidence in civil procedural law protect the interests of all parties involved in a case dispute. The neglect of the principle of proof results in the interests of one party being unprotected and even tending to be neglected [22].

The Law on Judicial Powers Number 48 of 2009 in conjunction with Law Number 14 of 1970 states in article 4 paragraph (1) that courts judge according to law and do not discriminate between people. This provision is further emphasized in paragraph (2) which states that courts assist justice seekers and try to overcome all obstacles and obstacles to achieve a simple, fast, and low-cost trial. The rule in article 4 paragraph (1) is known in the legal science doctrine as the principle of equality before the law. The provision for equality before the law is explicitly recognized in Article 27 paragraph (3) of the 1945 Constitution which states that all citizens have the same position in law and government and are obliged to uphold the law and government with no exceptions.

Equality before the law is not only explicitly recognized in the doctrine of jurisprudence and the law of judicial power. This recognition is confirmed in the 1945 Constitution as the basis of the state constitution. In general, the basis for equality before the law is very strong, and ignoring this provision means directly ignoring state provisions. The application of the law of evidence in civil cases cannot be separated from the principles of procedural law. The principles of proof are a form of affirmation that must be carried out to realize a good orderly process. Ignoring this provision, as well as the nature of the characteristics of civil law seeking formal truth, will result in the decision being null and void.

The increasing pace and development of association in human life also affects aspects of legal development on the one hand. The presence of HIR and RBg as legal products several centuries ago, automatically cannot accommodate aspects of legal developments that occur, when based on social developments in everyday life, regarding legal events in the traffic of civil relations. The enactment of Law Number 11 of 2008 concerning Electronic Information and Transactions (ITE) as an acknowledgment of the emergence of electronic transactions can be said to be an effort towards legal reform. How not, in the law it is stated that the use of Information Technology and Electronic Transactions is carried out to provide a sense of security, justice, and legal certainty for Information Technology users and providers. The view on the use of Information and Electronic Transactions (ITE) when drawn from the perspective of the legal realm, certainly provides an understanding of the necessity to ensure justice and legal certainty for users of electronic transactions. Regarding this, it can be seen in the phrases "justice" and "legal certainty".

Regarding the problems that can become obstacles in trading transactions conducted through electronic media (e-commerce) and the practice of buying and selling electronically (online), it has an ambiguous influence on aspects of legal protection as well as aspects of legal certainty regarding the position of transactions conducted electronically., especially the position of electronic transcripts that can be used as a guide for the parties (business actors and consumers) in dealing with the emergence of civil relations disputes. The position of civil procedural law, as a series/stages in resolving and enforcing material civil law, plays an important role in aspects of legal protection as well as legal certainty for parties in civil relationship disputes, especially business actors on the one hand and consumers on the other [24].

Problems in dealing with civil relations disputes, both litigation, and non-litigation as a form of dispute resolution efforts that occur, play an important role in the stage of the dispute resolution process. One of the series of stages in the litigation and non-litigation dispute resolution process (arbitration) is the evidentiary process. Constraints faced related to the existence of the electronic transcript, as a form of acknowledgment of the existence of 100 transactions carried out by the parties resulted in problems arising from the perspective of legal protection. General provisions regarding the evidentiary process in Indonesian civil cases are based on civil procedural law which is spread out in various rules such as, HIR, RBg, Rv, WvK, Jurisprudence, International Agreements, and Doctrine.

Justice and legal certainty in the practice of using electronic transactions have not been able to provide complete legal protection in the traffic of civil relations, considering that transactions carried out electronically in the current traffic of civil relations, do not rule out the possibility of being carried out globally, and crossing barriers between nations. as well as the state, so that legal protection in electronic transactions by jurisdiction creates legal differences that are applied when a dispute occurs [23]. Problems encountered in 
civil relationship transactions conducted electronically, in addition to the applicable legal jurisdiction, the authors conclude that several problems that can become obstacles in the use of electronic transactions include aspects of electronic agreements, electronic signatures, as well as, buying and selling conducted electronically.

The characteristics of electronic documents that can be transferred or stored in several forms, enabling electronic documents in practice cases at trial are not found in one standard form of media, this can be done considering the nature of electronic information and/or electronic documents can be transferred into several forms of media another. Provisions regarding legal electronic evidence as evidence in law, are recognized in article 5 paragraph (2) which states that Electronic information and/or Electronic Documents and or their printouts as referred to in paragraph (1) are extensions of legal evidence following the law. events that take place in Indonesia. Electronic information and/or electronic documents as an extension of evidence in court, based on article 5 paragraph (2) hereinafter by the author can be said to be electronic evidence.

Referring to Law Number 11 of 2008 concerning Electronic Information and Transactions (ITE), what is meant by electronic evidence is any electronic information and/or electronic document, this indicates that electronic evidence is real, different from the evidence specified in the procedural law practice in court. This difference can be seen from the material aspect of the evidence, for example, written evidence in civil cases is found in physical form, which is written on paper. This provision, of course, will be different from electronic evidence which can be transferred in several analog, digital, or electromagnetic forms. For this reason, the position of electronic evidence that has been legally recognized and can be used in court practice is aimed at ensuring legal certainty and protection. In addition, to the problem of the position of electronic evidence, the authors are interested in comparing the position of electronic evidence-based on Law Number 8 of 1997 concerning Company Documents.

\section{CONCLUSION}

The position of electronic evidence in the process of proving civil cases in court from the juridical-normative aspect has been recognized as evidence legally and firmly in the practice of procedural law that applies in court. The presence of Law Number 11 of 2008 as a form of affirmation (legitimacy), the recognition of electronic information and/or electronic documents and/or their printouts is legally valid evidence and is an extension of legal evidence following applicable procedural law. in Indonesia, as long as the electronic information and/or electronic documents contained therein can be accessed, displayed, guaranteed for its integrity, and can be accounted for so that it can explain a situation. Affirmations regarding the position of electronic evidence in the process of proving civil cases in court can be agreed upon by parties bound in a civil relationship to enter into a proof agreement. Situations like this can be interpreted, that electronic evidence can be used in the trial if desired by the parties through a proof agreement. The strength of evidence inherent in an electronic evidence instrument is juridicallynormatively equivalent to a document written on paper. This affirmation means that the strength of evidence attached to electronic evidence in civil cases can be equated with the strength of proof of written evidence (letters). The power of electronic evidence does not apply to letters which according to the law must be made in written form; and letters and documents which according to the law must be made in the form of a notarial deed or a deed made by the official making the deed. Concerning the proving power of an electronic signature, it can be formulated that there is a valid force attached to it, such as with the position of a manual signature. It can be understood that the binding power of a signature is binding on the parties involved in a signing affair.

\section{REFERENCES}

[1] Dikdik M. Airef Mansur and Elisatris Gultom, 2009, Cyber Law: Legal Aspects of Information Technology. Bandung : Refika Aditama.

[2] Fakhriah Ela Laila, 2009, Electronic Evidence in the Bandung Civil Evidence System: Alumni.

[3] Fuady Munir, 2012, Legal Theory of Evidence: Criminal and Civil. cet. I; Bandung PT. Image of Aditya Bakti.

[4] Hadikusuma Hilman, 2010, Indonesian Legal Language, Cet. IV; Bandung : Alumni.

[5] Harahap M Yahya, 2004, Civil Procedure Law on Lawsuits, Trials, Confiscations, Evidence, and Court Decisions, Jakarta: Sinar Graphic.

[6] Manan Abdul, 2009, Law Changing Aspects. cet. III; Jakarta : Kencana.

[7] Marzuki Peter Mahmud, 2010, Legal Research, Jakarta,: Kencana Prenada.

[8] Mertokusumo Sudikno, 2007, Indonesian Civil Procedure Code revised edition, Yogyakarta: Liberty.

[9] M. Natsir Asnawi, Indonesian Civil Case Evidence Law: A Contextual Study of Systems, Principles, Principles, Impositions, and Standards of Evidence.

[10] Republic of Indonesia, Law Number 11 of 2008 concerning Information and Electronic Transactions article 4.

[11] Retnowulan Sutantio and Iskandar Oeripkartawinata, Civil Procedure Law in Theory and Practice.

[12] Subekti R, 1999, Law of Evidence. cet. XII; Jakarta: Pradnya Paramita.

[13] Sunggono Bambang , 2007, Legal Research Methodology, Jakarta: PT.Raja Grafindo Persada.

[14] Fakhriah, Efa Laela, Electronic Evidence in Civil Evidence Systems, Bandung: Alumni, 2009.

[15] Harahap, M. Yahya, Some Reviews of Legal Issues, Book One, Bandung: Citra Aditya Bakti, 1997.

[16] Harianto, Dedi, Changes in Law and Society, Medan: Meeting Materials for Lectures on Sociology of Law, USU Postgraduate Legal Studies Program, 22 November 2011.

[17] Irsan, Koesparmono, Legal Studies Concerning the Legal Power of Electronic Evidence, Jakarta: National Legal Development Agency, 1996. 
[18] Kansil, CST, Introduction to Indonesian Law and Legal Administration, Jakarta: Balai Pustaka, 1989.

[19] Lubis, M. Solly, Law Politics, Edition 2, Medan: PT. Softmedia, 2011.

[20] Indonesian Consultative Assembly, Correctional Guidelines for the 1945 Constitution of the Republic of Indonesia: In accordance with the Order of Chapters, Articles, and Paragraphs, Jakarta: Secretariat General of the People's Consultative Assembly of the Republic of Indonesia, 2010.
[21] Ramli, Ahmad M., Towards Legal Certainty in the Field: Information and Electronic Transactions, Jakarta: Communications and Information Department, 2007.

[22] Saleh, K. Wantjik, Civil Procedure Law: RBG/HIR, Jakarta: Ghalia Indonesia, 2002.

[23] Sikumbang, Jusmadi, Knowing Sociology and Legal Saciology, Medan: Pustaka Bangsa Press, 2010.

[24] Supraptomo, Heru, Law and Computers, Bandung: Alumni, 1996. Syahrin, Alvi, Some Legal Problems, Medan: PT. Softmedia, 2009. 